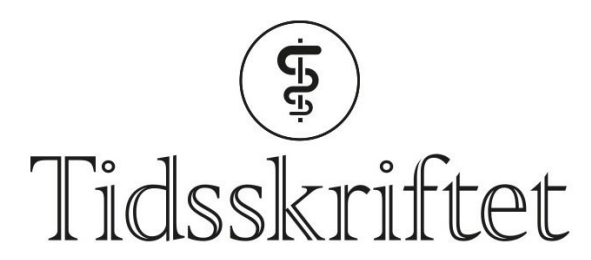

DEN NORSKE LEGEFORENING

\title{
Farvel, solopraksis
}

REDAKSJONELL KOMMENTAR

\section{ØYVIND STOPLE SIVERTSEN}

E-post: oyvind.stople.sivertsen@tidsskriftet.no

Øyvind Stople Sivertsen er allmennlege i spesialisering og medisinsk redaktør i Tidsskriftet

Handlingsplanen for allmennlegetjenesten er en invitasjon til å jobbe i team. Ikke alle norske fastleger vil være fornøyde med det.

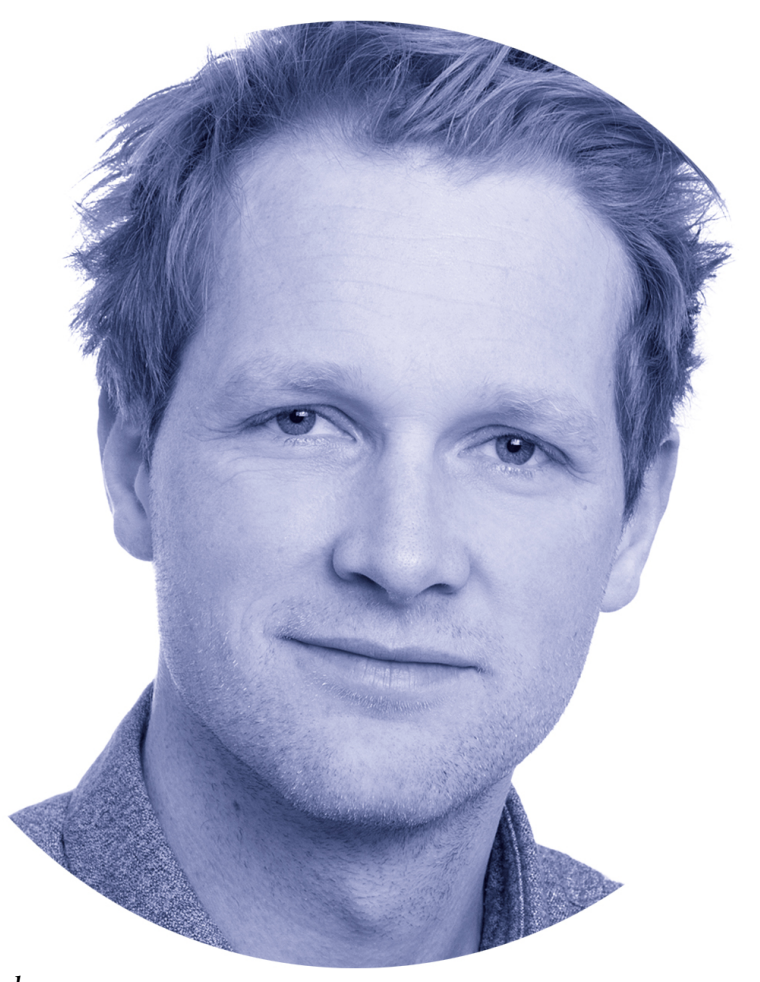

Foto: Sturlason

Mandag kom den. Lenge varslet, bredt utredet. Handlingsplanen for allmennlegetjenesten 2020-24 er på 58 sider og er verdt omtrent 1,6 milliarder kroner (1). Den er et resultat av langvarig dialog mellom Helse- og omsorgsdepartementet, Legeforeningen, Kommunenes sentralforbund (KS) og Oslo kommune, og beskriver hvordan partene skal jobbe frem en robust fastlegeordning, med faglig sterke allmennlegetjenester.

Fastlegeordningen er i krise. Denne planen skal gjenreise ordningen og gjøre det mer attraktivt å være fastlege.

Dette skal blant annet sikres gjennom å beholde dagens leger. Delvis ved hjelp av at basistilskuddet, kronebeløpet fastlegene får per pasient på listen sin, økes frem til pasient 
nummer 1 ooo. Etter dette holdes basistilskuddet uendret. For 2020 foreslås det en $\emptyset$ kning på 78 kroner per pasient.

Skal man passe inn i norsk allmennmedisin fremover, må man med andre ord like å jobbe med andre og man må jobbe fra andre steder enn bare sitt eget kontor

I tillegg vil regjeringen gjøre det mer attraktivt for unge leger å velge spesialiteten ved å sikre stabil inntekt til de som tjener minst. Enten gjennom forpliktende avtaler med fastlønn fra kommunene eller ved et garantert basistilskudd for 500 pasienter, uavhengig av hvor få som faktisk står på listen. Store deler av de friske midlene går til dette.

Handlingsplanen handler om penger. Men den har mer i seg enn det. Det er lange, etterlengtede avsnitt om kvalitet og det er gode beskrivelser av utfordringene i fastlegeordningen. Jeg opplever at departementet har forstått arbeidssituasjonen til fastlegene og at fornuftige tiltak er på vei. Blant annet pekes det på at tilgjengeligheten til fastlegene har gått ned grunnet stort arbeidspress (2). Kombinert med utstrakt bruk av vikarer fører det til at jo sykere en pasient er, jo mindre fornøyd vil vedkommende være. Behovene til pasienter med omfattende behov blir ikke møtt.

Mest av alt peker handlingsplanen ut en retning, med nøkkelordet samarbeid.

I 2018 jobbet det 4887 fastleger i Norge (3). $27 \%$ av disse var 39 år eller yngre. Totalt er $31 \%$ av fastlegene over 55 år. Men kanskje mer urovekkende for myndighetene: $14 \%$ av landets fastleger driver fremdeles solopraksis. Ytterligere 40 \% er i relativt små kontorfellesskap med to eller tre leger.

Dette rimer dårlig med internasjonale allmennmedisinske trender. Verdens allmennlegeforening (Wonca) har som gullstandard en teambasert primærhelsetjeneste i større grupper med en allmennlege som leder (4). I Norge gjennomføres nå pilotprosjekt med primærhelseteam, hvor fastlege, sykepleier og helsesekretær inngår (5). De fleste endringer i finansieringen til fastlegene de siste årene fremholder og honorerer tverrfaglig samarbeid, enten med andre yrkesgrupper eller med kolleger fra spesialisthelsetjenesten.

Handlingsplanen beskriver oppfølgingsteam og helsefellesskap, nye konstruksjoner som er laget for å holde tak i henholdsvis pasienter med sammensatte lidelser og helsepersonell med sammensatte oppgaver. I begge disse nyvinningene er fastlegene sentrale. I tillegg skal gruppeavtaler i fastlegeordningen utredes. Det betyr at en fastlegegruppe sammen har ansvaret for listepasientene, dette for å unngå at legene blir sittende alene uten å dra nytte av kollegers kompetanse.

Diskusjoner om fastlegeordningen ender som regel opp med å handle om penger

Skal man passe inn i norsk allmennmedisin fremover, må man med andre ord like å jobbe med andre og man må jobbe fra andre steder enn bare sitt eget kontor. Mange steder fordrer det at legen må gi fra seg noe av sin autonomi. I retur får man kanskje verdifull innsikt, avlastning og behov for reorganisering. Men, som Legeforeningen har advart mot, er det mange fallgruver og flere uavklarte ansvarsforhold ved slike endringer (6).

Selv om mye er likt, følger ikke handlingsplanen alle intensjonene fra fastlegeordningen slik denne var ment å være da den ble opprettet i 2001. Men verden ser litt annerledes ut nå. Det er derfor gledelig å registrere at det meste av handlingsplanen ikke er tilpasset utfordringer fra 2001, men 2021. Det er antakelig en mer sammensatt og mer komplisert arbeidshverdag nå, med langt flere aktører involvert. Fastlegene selv har gjennom fastlegeevalueringen pekt på at det kan bli ensomt i allmennpraksis. Det er sannsynlig at en del av løsningen er mer samarbeid med andre leger og andre faggrupper.

Diskusjoner om fastlegeordningen ender som regel opp med å handle om penger. Det er en grunn til at onde tunger anklager norske fastleger for å følge en modifisert utgave av den hippokratiske ed: Iblant helbrede, ofte lindre, alltid takste. Opptrappingsplanen for allmennlegetjenesten gir kanskje håp om at det siste ordet heller kan bli samarbeide, og at 
det kan gi trøst til både pasienter, ordningen og legene selv.

\section{LITTERATUR:}

1. Helse- og omsorgsdepartementet. Handlingsplan for allmennlegetjenesten. https://www.regjeringen.no/contentassets/96f6581333ee48559cdabf23c8772294/handlingsplan-for-allm ennleger.pdf Lest 12.5.2020.

2. EY og Vista analyse. Evaluering av fastlegeordningen.

https://www.regjeringen.no/contentassets/7cd212bf5fo642c1a5dod48ofog23e6d/evaluering-av-fastlegeo rdningen-sluttrapport-fra-ey-og-vista-analyse.pdf Lest 12.5.2020.

3. Helsedirektoratet. Fastlegestatistikk 2018.

https://www.helsedirektoratet.no/statistikk/fastlegestatistikk Lest 12.5.2020.

4. Wonca News. Global Family Doctor.

https://www.globalfamilydoctor.com/News/WHOEmphasisonPHCgainsinternationalsupport.aspx Lest 12.5.2020.

5. Helsedirektoratet. Primærhelseteam - pilotprosjekt.

https://www.helsedirektoratet.no/om-oss/forsoksordninger-og-prosjekter/primaerhelseteam-pilotpro sjekt Lest 12.5.2020.

6. Legeforeningen. Høringssvar fra legeforeningen: Pilot primærhelseteam.

https://www.legeforeningen.no/contentassets/94863aaod1984a7a8o3de77a1oeeb52c/hoeringssvar-pilot -primarhelseteam-hoering-av-endringer-i-regelverket-for-a-gjennomfore-piloten.pdf Lest 12.5.2020.

Publisert: 12. mai 2020. Tidsskr Nor Legeforen. DOI: 10.4045/tidsskr.20.0430

(C) Tidsskrift for Den norske legeforening 2020. Lastet ned fra tidsskriftet.no 